\title{
sciendo
}

DOI: $10.2478 / \mathrm{fv}-2018-0014$

FOLIA VETERINARIA, 62, 2: 30-34, 2018

\section{A SLAUGHTERHOUSE SURVEY FOR PORCINE CIRCOVIRUS TYPE 2 IN COMMERCIAL PIGS IN IBADAN, SOUTHWEST NIGERIA}

\author{
Aiki-Raji, C. O., Adebiyi, A. I., Oluwayelu, D. O. \\ Department of Veterinary Microbiology, University of Ibadan, Ibadan \\ Nigeria \\ ogloryus@yahoo.com
}

\section{ABSTRACT}

Porcine circovirus type 2 (PCV2) is recognized as one of the most important agents of reproductive disorders in gilts and sows worldwide. It is associated with considerable economic losses in the swine industry due to the unthriftiness, and variable morbidity and mortality it causes in pigs. In spite of the devastation caused by this virus to the global pig industry, there is little or no report of its occurrence in Nigeria. Hence, a slaughterhouse based survey was conducted to determine the prevalence of PCV2 infections in pigs in Ibadan, southwest Nigeria. Using a commercial ELISA kit, 364 pig sera collected from a major abattoir were screened for IgG antibodies against PCV2. The overall prevalence of anti-PCV2 antibodies in the pigs was $1.4 \%(5 / 364)$, with more female pigs $(4 / 237,1.7 \%)$ being seropositive than males $(1 / 127$, $0.8 \%)$. Since there is no routine vaccination against this swine disease in Nigeria, thus the antibodies detected in the pig sera indicated a natural exposure to the virus. The absence of clinical disease in the pigs also suggests the possibility of a carrier status for these animals and shows that they could serve as hosts for the perpetuation of the disease. These findings underscore the need for continuous surveillance for PCV2 among pigs in Nigeria in order to determine its contribution to production losses incurred in the Nigerian swine industry and aid the development of prevention and control strategies against the disease.

Key words: antibodies; commercial pigs; Nigeria; porcine circovirus type 2 ; slaughterhouse

\section{INTRODUCTION}

Porcine circoviruses (PCV) are small non-enveloped DNA viruses containing a unique single-stranded circular genome (31). Two species of PCV have been identified; porcine circovirus type 1 (PCV1), and porcine circovirus type 2 (PCV2). According to different studies [6, 32, 33], PCV1 does not cause clinical disease and is non-pathogenic in pigs. However, PCV2 is the primary causative agent of several syndromes collectively known as porcine circo- 
virus-associated disease (PCVAD) including: systemic or post-weaning multi-systemic wasting syndrome [17], respiratory (18), and enteric [19] diseases in pigs.

Porcine circovirus type 2 is recognized as one of the most important viruses causing severe economic impact in the swine industry worldwide and it has been described as causing different conditions depending on the virus, host immunity, co-infections and other environmental characteristics [22, 28]. PCV2 can be transmitted in several ways with the main route being by oro-nasal contact with infected faeces, urine or directly with infected pigs $[9,23,28]$. In addition, PCV2 is shed in respiratory, oral and urinary secretions, and faeces in both clinically affected, as well as in infected but apparently healthy pigs [28]. Generally, a clinical disease directly associated with PCV2 is not very common. However, in the subclinical infection, the presence of PCV2 can be responsible for production losses, mostly due to growth retardation and reduced average daily weight gain. Also, the infection of sows can lead to late-term abortions and stillbirths [22].

The Food and Agriculture Organization [13] estimated the per capita food availability of Nigerians as $2603 \mathrm{kcal} /$ day of which meat contributed only $3 \%$. This low level contribution of meat to the daily food intake of Nigerians compared, for instance, with the United States of America where meat contributes $12 \%$ of the total intake of 3825 $\mathrm{kcal} /$ day is further worsened by the scourge of infectious diseases such as African swine fever which negatively impact the country's swine population. With the growing demand for animal protein and the need to access regional and international markets for animals and animal products, continuous monitoring of animal diseases of economic importance in the country becomes imperative. Therefore, in Nigeria where pig production is becoming increasingly popular and with an estimated pig population of about seven million [14], there is a need to investigate the presence of infectious diseases that affect pig productivity. Previous studies $[2,4]$ based on slaughtered pigs at a major municipal abattoir in southwest Nigeria revealed serological evidence of viral diseases such as classical swine fever and porcine foot-and-mouth disease which hitherto had not been reported in Nigeria. However, although several studies have reported PCV2 in pigs elsewhere [10, 15, 34], there is a paucity of information on this disease in pigs in Nigeria. According to Segales [30], serum is the most commonly used sample to assess PCV2 antibodies and genome detection. Consequently, slaughterhouse surveys may provide an ease of sample collection during slaughter for the detection of antibodies against PCV2. Moreover, slaughterhouses are reported as critical points in the meat production scale, as well as key components of the disease control chain among animals and humans [1].

Thus, this study was carried out to determine the seroprevalence of PCV2 among apparently healthy, unvaccinated pigs slaughtered at the Bodija municipal abattoir, in Ibadan, southwest Nigeria.

\section{MATERIALS AND METHODS}

\section{Study area and animals}

A total of 364 apparently healthy pigs were randomly selected at the Bodija municipal abattoir located in Ibadan, the capital city of Oyo State in southwest Nigeria. They comprised Large White $(n=255)$, Duroc $(n=84)$ and Large Black $(n=25)$ breeds. Pigs slaughtered for human consumption at this abattoir were brought in from different parts of the region and may thus give a reasonable representation of the disease pattern in pigs in the region [4]. The ages of the pigs could not be determined but interaction with the pig suppliers (mainly smallholder farmers) revealed that they were adult pigs culled and sold off due to declining reproductive performance as a result of ageing. The pig slaughterhouse workers were interviewed on veterinary services and observed for any form of meat inspection in the pig slaughterhouse.

\section{Sample collection and storage}

Blood was aseptically collected into labelled plain sample bottles at slaughter from each of 364 pigs (127 males and 237 females). The blood samples were left at room temperature for about one hour to clot. Separated sera were stored at $-20^{\circ} \mathrm{C}$ until tested.

\section{Detection of serum anti-PCV2 IgG antibodies}

The sera were screened by an indirect enzyme-linked immunosorbent assay (ELISA) (Shenzhen Lvshiyuan Biotechnology, China) for the presence of IgG antibodies to PCV2 according to the manufacturer's instructions. The test kit, which was based on the solid-phase ELISA principle, utilized PCV2 antigen-coated microtitre plates. The test serum was first added to the antigen-coated plates. 
This was followed by addition of the enzyme-labelled conjugate (anti-pig IgG antibody) which specifically bound with the complex of coated antigen and PCV2 antibody on the microtitre plate. The substrate (tetramethylbenzidine) was subsequently added and the reaction terminated with a stop solution. The optical density (OD) values were read at dual wavelengths of 450 and $630 \mathrm{~nm}$. Valid results were obtained when the average OD value of the PCV2 positive control was $\geq 0.40$ and that of the negative control was less than 0.20 . Samples with OD value $>0.40$ and $<0.40$ were considered positive and negative, respectively.

\section{Statistical analysis}

The results from serology were analysed using Graph Pad prism version 5.0 (Graph Pad software, San Diego, CA, USA). The significance of differences in seroprevalence obtained based on the breed and sex of pigs was evaluated by the Chi-square test. A two-tailed P-value of 0.05 was considered statistically significant.

\section{RESULTS AND DISCUSSION}

The overall prevalence of anti-PCV2 antibodies in the pig sera was $1.4 \%(5 / 364)$, with more female pigs (4/237, $1.7 \%)$ being seropositive than males (1/127, $0.8 \%)$. All of the seropositive pigs were of the Large White breed, while none of the samples from the Duroc or Large Black pigs were positive. Also, based on the interview conducted among the slaughterhouse workers and our observations, it was discovered that there was no form of veterinary service or meat inspection at the pig slaughterhouse.

Slaughterhouses are a source of helpful information on the incidence of animal diseases and conditions including diseases of zoonotic and economic importance. Hence, abattoir or slaughterhouse surveys are essential components of infectious disease control and eradication programmes worldwide [8]. In the present study which is part of ongoing surveillance for porcine viruses of economic importance in Nigeria $[2,3,4]$, the detection of PCV2 IgG antibodies in asymptomatic pigs slaughtered at a major abattoir in southwest Nigeria indicates natural infection with the virus since vaccination against the disease is not practised in the country. It was observed in this study that there was no meat inspection in the pig slaughterhouse probably due to lack or inadequate veterinary personnel. This corroborates the findings of previous workers who reported that many abattoirs and slaughter slabs in developing countries have poor slaughter and meat inspection facilities [1, 2, 25].

The low $(1.4 \%)$ prevalence of PCV2 antibodies obtained in apparently healthy, unvaccinated adult pigs in this study suggests a low level exposure of the pigs to PCV2 as of the time of sample collection. Considering that PCV2 replicates first in the tonsils $[6,27]$, there may be the possibility of detecting higher level of antibodies in oral fluids [26]. However, this possibility could not be ascertained as oral fluids were not collected for this study. We therefore recommend the collection of both sera and oral fluids for future PCV2 surveillance studies in Nigeria.

Furthermore, this finding is consistent with earlier reports that PCV2 can be detected in the absence of clinical evidence of infection, suggesting the occurrence of subclinical infections or virulence variations [20] and is of veterinary importance because the infection of sows can lead to significant reproductive losses, mostly due to lateterm abortions, stillbirths and birth of piglets too weak to survive [22]. More importantly, PCV2 is an endemic and very stable virus [26] that may persist in pens [12] and it has been demonstrated that pigs subclinically infected with PCV2 may excrete medium to high loads of the virus in faeces $[21,24]$. In addition, $\mathrm{C}$ s a $\mathrm{k}$ et al. [11] reported the shedding of the virus during subclinical infection in the presence of post-infection antibodies. Hence, these pigs could serve as reservoirs shedding the virus into the environment. This makes them potential sources for perpetuation of this viral disease that causes great economic losses as a result of the death of young animals, abortions, reduced fertility and decreased quality and quantity of the meat [26] as a result of prolonged time to slaughter weight, decreased nutritional use efficiency, and weight loss in more susceptible breeds and animals, especially when adequate contact prevention devices have not been implemented on commercial farms [12].

The diagnosis of PCV2 disease based on clinical signs is often difficult because symptoms may vary considerably depending on the virus, age of animals and production system [29]. This may account for the paucity of published information on PCV2 in Nigeria, and possibly explain the under-reporting or lack of reporting on PCV2 in the country.

To our knowledge, this study is the first report on PCV2 disease in Nigeria. The findings reveal that PCV2 presently 
circulates among pigs in Ibadan, southwest Nigeria. Since this disease is considered of high economic importance due to its contribution to ill-thriftiness as well as the variable morbidity and mortality rates it causes in pigs $[5,16]$, there is a need for continuous surveillance for PCV2 among pigs in the country. Further studies aimed at identifying and characterizing PCV2 strains circulating in Nigeria are under consideration.

\section{REFERENCES}

1. Adesokan, H.K., Oyedotun, A. A., Ishola, O.O., Cadmus, S. I. B., 2012: Management and operations of selected slaughter houses in Oyo and Lagos states, south western Nigeria: public health implications. Trop. Vet., 30, 161-169.

2. Aiki-Raji, C.O., Adebiyi, A.I., Adeyemo, I. A., Fagbohun, O.A., Oluwayelu, D.O., 2014: Seroprevalence of classical swine fever antibodies in slaughtered pigs at Bodija municipal abattoir, Ibadan, South West Nigeria. Europ. J. Sci. Res., 126, 402-407.

3. Aiki-Raji, C. O., Adebiyi, A. I., Abiola, J. O., Oluwayelu, D. O., 2017: Prevalence of porcine reproductive and respiratory syndrome virus and porcine parvovirus antibodies in commercial pigs, southwest Nigeria. Beni-Suef Univ. J. Basic Appl. Sci., http://dx.doi.org/10.1016/j.bjbas.2017.07.006.

4. Aiki-Raji, C.O., Oluwayelu, D.O. Adeyemo, I. A. Adebiyi, A.I., 2016: Seroprevalence of foot-and-mouth disease in slaughtered pigs in Ibadan, Southwest Nigeria, Alex. J. Vet. Sci., 48, 18-22.

5. Alarcon, P., Velasova, M., Werling, D., Stark, K. D., Chang, Y.M., Nevel, A., et al., 2011: Assessment and quantification of post-weaning multi-systemic wasting syndrome severity at farm level. Prev. Vet. Med., 98, 19-28.

6. Allan, G. M., McNeilly, F., Cassidy, J.P., Greilly, A., Adair, B., Ellis, W. A., Mc Nulty, M.S., 1995: Pathogenesis of porcine circovirus; experimental infections of colostrum deprived piglets and examination of pig foetal material. Vet. Microbiol., 44, 49-64.

7. Allan, G. M., McNeilly, F., Meehan, B.M., Ellis, J. A., Connor, T. J., McNair, I., et al., 2000: A sequential study of experimental infection of pigs with porcine circovirus and porcine parvovirus: immunostaining of cryostat sections and virus isolation. J. Vet. Med., 47, 81-94.

8. Al-Qudah, K.M., Al-Majali, A.M., Obaidat, M.M., 2008: A study on pathological and microbiological conditions in goats in slaughterhouses in Jordan. Asian J. Anim. Vet. Adv., 3, 269-274.

9. Bolin, S.R., Stoffregen, W.C., Nayar, G.P., Hamel, A.L., 2001: Post-weaning multisystemic wasting syndrome induced after experimental inoculation of cesarean-derived, colostrum-deprived piglets with type 2 porcine circovirus. J. Vet. Diagn. Invest., 13, 185-194.

10. Chen, Q.X., Ye, J.X., Zhou, J.Y., Chen, T.F., Shen, H.G., Shang, S. B., 2007: Serological survey of serum antibodies against porcine circovirus type 2 (PCV2) in swine, chicken, duck, goat and cattle from Zhejiang province, China. Revue Méd. Vét., 158, 458-462.

11. Csank, T., Pistl, T., Pollakova, T., Bhide, T., Herich, T., 2013: Dynamics of antibody response and viraemia following natural infection of porcine circovirus 2 (PCV-2) in a conventional pig herd. APMIS, 121, 1207-1213.

12. Dvorak, C.M., Lilla, M.P., Baker, S.R., Murtaugh, M.P., 2013: Multiple routes of porcine circovirus type 2 transmission to piglets in the presence of maternal immunity. Vet. Microbiol., 166, 365-374.

13. Food and Agriculture Organization (FAO), 2009: Food and Agriculture Organization of the United Nations. The State of Food and Agriculture 2009: Livestock in the Balance, 2010, 176 pp., www.fao.org.

14. Food and Agriculture Organization (FAO), 2014: Animal Production and Health, 2014. Cited April 11, 2017. Available at http://www.fao.org/faostat/en.

15. Gillespie, J., Opriessnig, T., Meng, X. J., Pelzer, K., Buechner-Maxwell, V., 2009: Porcine circovirus type 2 and porcine circovirus-associated disease. J. Vet. Intern. Med., 23, 11511163.

16. Grau-Roma, L., Stockmarr, A., Kristensen, C. S., Enoe, C., López-Soria, S., Nofrarías, M., et al., 2012: Infectious risk factors for individual post weaning multisystemic wasting syndrome (PMWS) development in pigs from affected farms in Spain and Denmark. Res. Vet. Sci., 93, 1231-1240.

17. Harding, J., Clark, E., 1997: Recognizing and diagnosing post-weaning multisystemic wasting syndrome (PMWS). J. Swine Health Prod., 5, 201-203.

18. Harms, P. A., Halbur, P. G., Sorden, S. D., 2002: Three cases of porcine respiratory disease complex associated with porcine circovirus type 2 infection. J. Swine Health Prod., 10, 27-30.

19. Kim, J., Ha, Y., Jung, K., Choi, C., Chae, C., 2004: Enteritis associated with porcine circovirus 2 in pigs. Can. J. Vet. Res., $68,218-221$. 
20. Larochelle, R., Magar, R., D’allaire, S., 2003: Comparative serologic and virologic study of commercial swine herds with and without post-weaning multisystemic wasting syndrome. Can. J. Vet. Res., 67,114-120.

21. Lopez-Rodriguez, A., Dewulf, J., Meyns, T., Del-Pozo-Sacristan, R., Andreoni, C., Goubier, A., et al., 2016: Effect of sow vaccination against porcine circovirus type 2 (PCV2) on virological profiles in herds with or without PCV2 systemic disease. Can. Vet. J., 57, 619-628.

22. Madec, F., Rose, N. Grasland, B., Cariolet, R. Jestin, A., 2008: Post-weaning multisystemic wasting syndrome and other PCV2-related problems in pigs: a12-year experience. Transbound. Emerg. Dis., 55, 273-283.

23. Magar, R., Larochelle, R., Thibault, S., Lamontagne, R., 2000: Experimental transmission of porcine circovirus type 2 (PCV2) in weaned pigs: A sequential study. J. Comp. Pathol., $123,258-269$.

24. McIntosh, K.A., Tumber, A., Harding, J. C., Krakowka, S., Ellis, J.A., Hill, J. E., 2009: Development and validation of a SYBR green real-time PCR for the quantification of porcine circovirus type 2 in serum, buffy coat, faeces and multiple tissues. Vet. Microbiol., 133, 23-33.

25. Mkupasi, E. M., Ngowi, H. A., Nonga, H., 2011: Prevalence of extra-intestinal porcine helminth infections and assessment of sanitary conditions of pig slaughter slabs in Dar es Salaam city, Tanzania. Trop. Anim. Hlth. Prod., 43, 417-423.

26. Opriessnig, T., Meng, X. J., Halbur, P.G., 2007: Porcine circovirus type 2 associated disease: update on current terminology, clinical manifestations, pathogenesis, diagnosis and intervention strategies. J. Vet. Diagn. Invest., 19, 591-615.
27. Rosell, C., Segales, J., Plana-Duran, J., Balasch, M., Rodriguez-Arrioja, G. M., Kennedy, S., et al., 1999: Pathological, immunohistochemical and in situ hybridization studies of natural cases of post-weaning multisystemic wasting syndrome (PMWS) in pigs. J. Comp. Pathol., 120, 59-78.

28. Segales, J., Allan, G. M., Domingo, M., 2005: Porcine circovirus diseases. Anim. Hlth. Res. Rev., 6, 119-142.

29. Segales, J., Kekarainen, T., Cortey, M., 2013: The natural history of porcine circovirus type 2: from an inoffensive virus to a devastating swine disease? Vet. Microbiol., 165, 13-20.

30. Segales, J., 2012: Porcine circovirus type 2 (PCV2) infections: clinical signs, pathology and laboratory diagnosis. Virus Res., $164,10-19$.

31. Tischer, I., Gelderblom, H., Vettermann, W., Koch, M.A., 1982: A very small porcine virus with circular single-stranded DNA. Nature, 295, 64-66.

32. Tischer, I., Mields, W., Wolff, D., Vagt, M., Griem, W., 1986: Studies on epidemiology and pathogenicity of porcine circovirus. Arch. Virol., 91, 271-276.

33. Tischer, I., Rasch, R., Tochtermann, G. 1974: Characterization of papovavirus-and picornavirus-like particles in permanent pig kidney cell lines. Zentralbl. Bakteriol. (Orig A), 226, $153-167$.

34. Walker, I. W., Konoby, C.A., Jewhurst, V.A., McNair, I., McNeilly, F., Meehan, B. M., et al., 2000: Development and application of a competitive enzyme-linked immunosorbent assay for the detection of serum antibodies to porcine circovirus type 2. J. Vet. Diagn. Invest., 12, 400-405.

Received December 9, 2017

Accepted April 11, 2018 